\title{
Weathering Controls on Mechanisms of Carbon Storage in Grassland
}

\section{Soils}

C.A. Masiello ${ }^{1,{ }^{* *}}$, O.A.Chadwick ${ }^{2}$, J. Southon ${ }^{1,3}$, M.S.Torn ${ }^{4}$, J.W.Harden ${ }^{5}$

${ }^{1}$ Center for Accelerator Mass Spectrometry, Lawrence Livermore National Laboratory, Livermore, CA 94550

${ }^{2}$ Department of Geography, UC Santa Barbara, Santa Barbara, CA 93106

${ }^{3}$ Department of Earth System Science, UC Irvine, Irvine, CA 92697-3100

${ }^{4}$ Center for Isotope Geochemistry, Lawrence Berkeley National Laboratory, One Cyclotron Road MS 90-1116, Berkeley, CA 94720

${ }^{5}$ US Geological Survey, 345 Middlefield Road ms 962, Menlo Park, CA 94025

${ }^{\dagger}$ Now at: Department of Earth Science, Rice University, Houston, TX 77005

*corresponding author

e-mail: masiello@gps.caltech.edu

\section{index terms:}

1055 Organic Geochemistry

1615 Biogeochemical Processes

1625 Geomorphology and Weathering 


\begin{abstract}
On a sequence of soils developed under similar vegetation, temperature and precipitation conditions, but with variations in mineralogical properties, we use organic carbon and ${ }^{14} \mathrm{C}$ inventories to examine mineral protection of soil organic carbon. In these soils, ${ }^{14} \mathrm{C}$ data indicates that the creation of slow-cycling carbon can be modeled as occurring through reaction of organic ligands with $\mathrm{Al}^{3+}$ and $\mathrm{Fe}^{3+}$ cations in the upper horizons, followed by sorption to amorphous inorganic Al compounds at depth. Only one of these processes, the chelation of $\mathrm{Al}^{3+}$ and $\mathrm{Fe}^{3+}$ by organic ligands, is linked to large carbon stocks. Organic ligands stabilized by this process traverse the soil column as dissolved organic carbon (both from surface horizons and root exudates). At our moist grassland site, this chelation and transport process is very strongly correlated with the storage and long-term stabilization of soil organic carbon.

Our ${ }^{14} \mathrm{C}$ results show that the mechanisms of organic carbon transport and storage at this site follow a classic model previously believed to only be significant in a single soil order (Spodosols), and closely related to the presence of forests. The presence of this process in the grassland Alfisol, Inceptisol, and Mollisol soils of this chronosequence suggests that this process is a more significant control on organic carbon storage than previously thought.
\end{abstract}




\section{Introduction}

Human use of fossil fuels has increased the atmospheric $\mathrm{CO}_{2}$ concentration beyond levels observed in more than the last four glacial cycles [Barnola et al., 2003], and some, but not all, components of terrestrial ecosystems are capable of absorbing a portion of this carbon. The soil organic carbon (OC) pool is of particular interest because it is at least twice as large as the atmospheric $\mathrm{CO}_{2}$ pool and annually exchanges $\sim 60 \times 10^{6}$ tons of carbon with the atmosphere via the terrestrial biosphere [Amundson, 2001]. The amount of soil OC and its turnover time depends in part on the soil's protective capacity; that is, how much carbon the soil is capable of sequestering [Baldock and Skjemstad, 2000]. Soil protective capacity is a function of ecosystem characteristics, climate, geomorphology, and soil mineralogy [Baldock and Skjemstad, 2000; Jenny, 1941]. Mineralogy plays a significant role in carbon storage because interactions with mineral surfaces effectively transfer OC from the rapid atmosphere-biosphere carbon loop to the more slowly cycling stable soil carbon pool. The soil dissolved organic carbon pool (DOC, material which passes an approximately $0.45 \mu \mathrm{m}$ filter) is the intermediary in many of these reactions (see, for example, [Kaiser and Zech, 2000]). In some cases the process of mineral sorption renders DOC almost completely inaccessible to microbial decay, increasing its turnover time to thousands of years; in other cases, interactions with soil inorganics may only slightly slow turnover [Guggenberger and Kaiser, 2003; Trumbore, 1997]. Mineral-organic interactions are particularly important because they bind up a significant fraction of the soil carbon pool, and their mechanisms of storage are intimately linked to the behavior of the soil DOC pool. Because the production of mineral-bound OC is connected to soil DOC production and transport, the stability of this 
mineral-bound pool may be vulnerable to hydrological and ecological changes. An accurate assessment of the size and storage mechanisms in the mineral-associated soil OC pool will allow us to better understand its response to climate change. One parameter essential to understanding mineral-OC interactions is carbon turnover time. Radiocarbon is an essential tool in tracking soil carbon storage mechanisms, because in many cases it is a direct measure of OC turnover times.

OC-mineral interactions are strongly driven by weathering processses. At first glance, this can be understood simply as a surface area phenomenon: weathering produces clays with much higher surface area than primary minerals, and those clays are more likely to have carbon sorption sites [Mayer, 1994]. However, surface sorption does not sufficiently explain organic carbon content in a number of systems [Mayer, 1999; Mayer, 2001], suggesting that weathering-related controls on carbon storage are more complex and likely related to the mineralogy and surface chemistry of secondary clays [Chorover et al., 2004; Guggenberger and Kaiser, 2003].

In humid regions where many soils are low in exchangeable calcium, soil OC content can be related to iron and aluminum concentrations, and in some cases soil OC protection is specifically related to the concentration of two classes of $\mathrm{Fe}$ and $\mathrm{Al}$ compounds produced as metastable intermediates during the process of soil weathering [Kaiser and Zech, 2000; Percival et al., 2000; Torn et al., 1997]. In these two cases, carbon-protecting mechanisms are related to 1) the presence of $\mathrm{Al}^{3+}$ and $\mathrm{Fe}^{3+}$ ions and 2) amorphous inorganic $\mathrm{Al}-\mathrm{Si}$ compounds. $\mathrm{Ca}^{2+}$ is related to carbon storage in neutral to alkaline soils through a mechanism similar to that of the $\mathrm{Al}^{3+}$ and $\mathrm{Fe}^{3+}$ ions. 
In the first class of carbon-protecting reactions, $\mathrm{Fe}^{3+}$ and $\mathrm{Al}^{3+}$ are chelated by organic acids to create one type of metastable intermediate: organo-metal complexes. The concentration of metal ions residing in organo-metal complexes can be approximated by extracting the soil with sodium pyrophosphate [McKeague et al., 1971], (although under some circumstances this extraction releases small amounts of additional forms of $\mathrm{Al}$ and Fe [Kaiser and Zech, 1996]). We abbreviate these chelated metal ions as $\mathrm{Fe}_{\mathrm{py}}$ and $\mathrm{Al}_{\mathrm{py}}$, and, when summed, as $\mathrm{S}_{\mathrm{py}}$. In a second type of reaction, release of $\mathrm{Fe}, \mathrm{Al}$, and Si during weathering of primary minerals leads to formation of metastable oxyhydroxides (often called 'noncrystalline minerals' or 'noncrystalline compounds') that have short-range crystal order, are highly hydrated, and tend to react with organic molecules to form innersphere bonds [Stumm, 1992]. Extraction of soils with ammonium oxalate measures the concentrations of both $\mathrm{Al}$ and $\mathrm{Fe}$ in these noncrystalline compounds and also in organometal complexes; the difference between $\mathrm{S}_{\mathrm{py}}$ and this measurement provides an approximation of the non-crystalline compound concentration alone. We abbreviate the non-crystalline concentration of $\mathrm{Al}$ and $\mathrm{Fe}$ as $\mathrm{Al}_{\text {ox-py }}$ and $\mathrm{Fe}_{\text {ox-py }}$ and, when summed, as $\mathrm{S}_{\text {ox-py. }}$. In some soils very high in non-crystallines, $\mathrm{Al}_{\text {ox }}$ and $\mathrm{Fe}_{\mathrm{ox}}$ alone can be used to estimate non-crystalline mineral concentrations [Percival et al., 2000].

Although higher concentrations of organo-metal complexes and noncrystalline compounds have been related to increased soil carbon inventory [Percival et al., 2000; Powers and Schlesinger, 2002; Torn et al., 1997] and DOC sorption [Kaiser and Zech, 2000], only noncrystalline compounds have been related to soil carbon turnover time, and only for soil formed on volcanic parent materials [Torn et al., 1997]. The distinction between inventory and turnover time is significant in understanding carbon protection; a 
mechanism which causes a large inventory and rapid turnover is not as good at carbon protection as one which causes a large inventory and slow turnover. Controls on inventory and turnover do not necessarily co-vary, either; a particular mineral may be highly reactive with OC, thus slowing OC turnover, but if present in low concentrations, it results in only slight increases in OC inventory. Carbon storage is most effective when inventory is high, turnover is slow, and the mechanism of OC storage is not saturated.

Although organo-metal complexes and noncrystalline compounds co-vary with carbon inventory, little is known about the direct effect these compounds on the turnover rates of soil carbon. This study addresses the relationship between the dependent variables carbon inventory and carbon turnover time and the independent variables organo-metal complexes and noncrystalline compounds in a series of humid, grassland soils formed on sandstone parent material.

\section{Site Description}

Through the Quaternary, changes in sea level have combined with tectonic uplift to produce wave-cut marine terraces along the west coast of North America. We sampled soils formed on terraces south of Eureka, CA, close to the mouth of the Mattole River (see Fig 1). These terraces are gently sloping bedrock straths that are covered by 1-3 m of beach deposits. Compared with the surrounding hilly landscape, the planar terrace surfaces are minimally eroded, leading to long periods of uninterrupted soil development characterized by substantial changes in soil properties such as clay content and mineral composition. These terraces range in geologic age from 3.9 to 240 ka [Merritts et al., 1991; Merritts et al., 1992]. Soil parent material is arkosic sandstone, siltstone, and shale. 
For discussion of soil mineralogy, see [Merritts et al., 1991]. Carbon storage at this field site was first discussed by Chadwick et al. [Chadwick et al., 1994a].

Soils formed on the Mattole terraces are Entic and Typic Hapludolls on the two youngest terraces, Pachic Haplumbrepts on the three intermediate terraces, and Typic Hapludalfs on the oldest terrace. They formed in a coastal region that experiences a cool, temperate Mediterranean climate [Merritts et al., 1992]. Mean annual air temperature is $12^{\circ} \mathrm{C}$ and mean annual precipitation is $>1000 \mathrm{~mm} / \mathrm{yr}$, the majority of which occurs between the months of October and May. The ecosystem is coastal California prairie, composed of perennial and annual grasses and annual forbs, and like most of the west coast of North America, has been used to graze cattle in the past. Over geologic time, these terraces have likely experienced a range of ecosystem conditions. Since $~ 1985$ this land has been under the care of the Bureau of Land Management and has not been grazed.

At many soil sequences it is difficult to assess the significance of metastable intermediate compounds in controlling carbon turnover for several reasons. First, metastable intermediates can covary with clay content, a proxy for a number of variables thought to be important in carbon storage (including surface area, texture, and hydrologic conductivity). Second, in less developed soils, both clay content and metastable intermediates increase with time; however, in more weathered soils there may be only very low concentrations of metastable intermediates remaining (cf. [Chadwick et al., 1999; Vitousek et al., 1997].) Finally, chelated organics $\left(\mathrm{S}_{\mathrm{py}}\right)$ and noncrystalline compounds $\left(\mathrm{S}_{\text {ox-py }}\right)$ frequently develop concurrently. The Mattole terraces are an ideal sampling site for deconvolving metastable intermediates from generalized soil 
development because this series includes soils from periods of both ingrowth and loss of metastable minerals, neither of which co-vary with soil clay content at these sites. Additionally, the individual forms of metastable intermediates, as represented by $\mathrm{S}_{\mathrm{py}}$ and $\mathrm{S}_{\mathrm{ox}-\mathrm{py}}$, do not covary.

\section{Methods}

Soils were sampled by horizon down to the bedrock strath; soil depths ranged from about 1 to $3 \mathrm{~m}$. A total of seven profiles were sampled from terraces whose ages have been previously estimated as: 3.9 ka, 29 ka, 40 ka, 118 ka, 124 ka (sites a and b), and 240 ka [Merritts et al., 1991]. Samples were air-dried and sieved to $2 \mathrm{~mm}$ prior to analysis. As part of earlier studies, aliquots were analyzed for mineralogical properties [Merritts et al., 1991; Merritts et al., 1992]: 1) sodium pyrophosphate, ammonium oxalate, and dithionite-citrate extractions were conducted following procedures outlined in McKeague and Day [McKeague and Day, 1966] and McKeague et al [McKeague et al., 1971]; 2) iron and aluminum released by the extracting solutions were measured using atomic absorption spectroscopy; and 3) clay percent was measured by sedimentation using the pipette methods (Soil Survey Laboratory Staff, 1992). Dithionitecitrate extractions measure $\mathrm{Fe}_{\mathrm{d}}$, which represents all pedogenic iron, both crystalline and non-crystalline. Bulk density was measured using a core sampler.

Kaolin, smectite, vermiculite, mica, and total interlayer minerals were quantified in the clay fraction of these soils using a combination of wet chemical and x-ray diffraction methods. After removal of OC via $\mathrm{H}_{2} \mathrm{O}_{2}$ oxidation [Jackson, 1968], clay was separated from sand and silt via wet sieving and repeated centrifugation and decantation [Jackson, 1968]. The following clay components were determined gravimetrically after 
sequential selective dissolution and analysis of the extracts by atomic absorption spectroscopy (AAS) for $\mathrm{SiO}_{2}, \mathrm{Al}_{2} \mathrm{O}_{3}$, and $\mathrm{Fe}_{2} \mathrm{O}_{3}$ as appropriate: noncrystalline (ammonium oxalate, $\mathrm{pH} 3.0$ in the dark), free sesquioxides (sodium dithionite - sodium citrate), poorly crystalline ( $0.5 \mathrm{M}$ sodium hydroxide boiling for 2.5 minutes), Al-hydroxy interlayer minerals (aka chloritic intergrade minerals) (heating at $300{ }^{\circ} \mathrm{C}$ and boiling with 0.5 M sodium hydroxide for 2.5 minutes), kaolin (kaolinite plus halloysite) (heating 550 ${ }^{\circ} \mathrm{C}$ and boiling with $0.5 \mathrm{M}$ sodium hydroxide for 2.5 minutes) [Alexiades and Jackson, 1966; Jackson, 1965; Jackson, 1968; Jackson et al., 1986]. Vermiculite was determined by the rubidium fixation method [Ross et al., 1989], mica by back calculation using total potassium data, and smectite from the cation exchange capacity of samples treated with potassium to block the interlayer cation exchange capacity [Jackson et al., 1986]. The chlorite content determination was based on weight loss between 300 and $950{ }^{\circ} \mathrm{C}$ after allocation of $\mathrm{OH}$-water to the other hydrous minerals determined [Alexiades and Jackson, 1966]. All mineral data have been previously reported [Chadwick et al., 1994b; Merritts et al., 1991], except for the clay mineral analyses (D. Hendricks, unpublished data).

For \%C, \%N, and carbon isotopic measurements, $<2 \mathrm{~mm}$ soil samples were gently ground with a mortar and pestle. Percent $\mathrm{C}$ and $\mathrm{N}$ values reported here were measured on a high temperature combustion $\mathrm{C} / \mathrm{N}$ analyzer. Samples for ${ }^{14} \mathrm{C}$ analysis were combusted in quartz tubing with $\mathrm{CuO}$ and $\mathrm{Ag}$. The resulting $\mathrm{CO}_{2}$ was recovered cryogenically, then converted to graphite via reduction over an Fe catalyst, and finally measured for ${ }^{14} \mathrm{C}$ by accelerator mass spectrometry (AMS) [Vogel et al., 1987]. Prior to graphitization, $\mathrm{CO}_{2}$ splits were taken for $\delta^{13} \mathrm{C}$ measurements and all ${ }^{14} \mathrm{C}$ values are corrected for ${ }^{13} \mathrm{C}$ (a standard technique to remove effects of biological fractionation on ${ }^{14} \mathrm{C}$ data, see [Stuiver 
and Polach, 1977]). In these humid environment soils, carbonates were non-existent and no acid pretreatment was required prior to elemental or isotopic analysis.

We calculated carbon and mineral inventories and carbon-weighted average ${ }^{14} \mathrm{C}$ signatures for each terrace by integrating over the top meter, where the vast majority of carbon is stored (Table 1), and for individual horizons (A, AB, and B - data not shown). Carbon inventories $\left(\mathrm{C}_{\text {tot }}\right)$ were calculated as:

$$
C_{\text {tot }}=\sum_{i=0 c m}^{i=100 c m} h_{i} \cdot \rho_{i} \bullet \% O C_{i} / 100
$$

where $\rho=$ horizon bulk density in $\mathrm{g} / \mathrm{cm}^{3}$ and $\mathrm{h}=$ horizon thickness in $\mathrm{cm}$. Profile mineral inventories were calculated similarly. Carbon-weighted average ${ }^{14} \mathrm{C}$ signatures were calculated as:

$$
F M_{\text {weighted }}=\frac{1}{C_{\text {tot }}} \cdot \sum_{i=0 \mathrm{~cm}}^{i=100 \mathrm{~cm}} F M_{\mathrm{i}} \bullet h_{i} \bullet \rho_{i} \bullet \% O C_{i} / 100
$$

where $\mathrm{FM}=$ the ${ }^{14} \mathrm{C}$ signature of each horizon reported as fraction modern, and where the radiocarbon signature of the atmosphere in 1950 had an FM = 1.000 (for details on reporting of ${ }^{14} \mathrm{C}$, see [Stuiver and Polach, 1977]). Radiocarbon values were weighted by the amount of carbon in the profile to distinguish between soils with small amounts of old carbon (poor at storing C) and soils with large amounts of old carbon (good at storing C). Radiocarbon values do not represent the 'age' of OC at these terraces; instead in these soils, ${ }^{14} \mathrm{C}$ values can be used as a measure of the average turnover time of many pools of carbon, all of which are continuously receiving modern carbon and releasing old carbon. Weighted FM values can be interpreted as a measure of how effectively a particular soil can sequester carbon, with lower FM values (closer to 0) 
indicating less ${ }^{14} \mathrm{C}$ and more effective carbon storage, and heavier FM values (closer to 1) indicating more ${ }^{14} \mathrm{C}$ and less effective carbon storage.

Detonation of nuclear weapons in the atmosphere in the 1960s and 1970s created a pulse of ${ }^{14} \mathrm{C}$ which is currently equilibrating with the biosphere and with soils. Estimation of soil OC turnover time based on ${ }^{14} \mathrm{C}$ measurements is affected by this transient 'bomb spike.' In the case of these soils, the bomb spike acts to our advantage by increasing the difference in FM between fast-cycling and slow-cycling soil carbon pools.

This series of soils has been studied previously as a chronosequence, and it has been shown that clay content increases with time. Percent OC also changes with time, increasing rapidly from the 3.9 ka to the 29 ka terraces, and continuing to increase at a slower rate in the more developed terraces. With time, these soils become progressively more weathered, becoming depleted in base cations and Si relative to $\mathrm{Al}$ and Fe. Clay mineral suites also change, and the amounts of pyrophosphate- and oxalate-extractable $\mathrm{Al}$ and Fe vary, reaching maxima at the intermediate-aged terraces [Merritts et al., 1991].

Our approach is to use this chronosequence as a suite of soils with different mineral compositions, but controlled for parent material, ecology, and climate. Our primary focus is on the mineral composition of the soils, to better understand the influence of mineral development on soil OC movement and storage. In this analysis, we have added two profiles (124b ka and $118 \mathrm{ka}$ ) which were excluded from the original chronosequence because they may have experienced geomorphic processes (likely erosion or deposition of alluvial or windblown material) which reset their mineralogical development to an earlier stage, precluding their use in previous strictly chronological 
studies. However, these sites retain the parent material, ecology, and climate controls necessary for our study and since we do not require an absolute chronology, we were able to include these samples here.

\section{Results}

As previously reported, clay mineral concentration increases with increased terrace weathering [Merritts et al., 1991; Merritts et al., 1992]. By contrast, the concentrations of $S_{p y}$ and $S_{\text {ox-py }}$ peak in the intermediately weathered soils and decline in the most weathered profiles [Merritts et al., 1991; Merritts et al., 1992]. Soils formed on the two least developed terraces are mineralogically different from the other terraces: the least developed soil profiles are dominated by the sand-size particles and primary minerals that characterize the present beach sand, whereas other profiles are dominated by variable amounts of residual weathering products (silicate clay minerals, $\mathrm{S}_{\mathrm{py}}$ and $\mathrm{S}_{\mathrm{ox}-}$ py).

\section{A. Carbon and radiocarbon inventories}

For the top meter, carbon inventories were lowest in the soil profile that had the most intact primary minerals and the least soil-formed clays (3.9 ka). This profile also was least effective at long-term carbon storage as measured by weighted FM (Fig 2a,b). This is consistent with both the low clay/high sand inventories of this profile and the low inventories of organic-binding $\mathrm{Al}$ and Fe complexes (Tables 1 and 2). Carbon inventories

peak and weighted ${ }^{14} \mathrm{C}$ inventories reach a minimum in the soil profiles sampled from the intermediate-age terraces (118ka and 124ka), although there are significant variations between the soil profiles sampled on the 124 ka terrace. There is a net decrease in soil carbon storage and a net increase in soil ${ }^{14} \mathrm{C}$ inventories between the profiles on the 118 
ka terrace and the 240 ka terrace, suggesting that these soils’ sequestration potential declines after the mineralogical development stage exhibited on the 118 ka terrace.

\section{B. Mineralogical correlations with OC storage}

In the top meter of the Mattole soils, organic matter content and weighted ${ }^{14} \mathrm{C}$ inventory correlate significantly with $\mathrm{Al}_{\mathrm{py}}$ and $\mathrm{Fe}_{\mathrm{py}}$, with correlation coefficient $\mathrm{R}$ values $>0.9$ and $\mathrm{p}$ values close to or less than $0.1 \%$ (where $\mathrm{p}$ is the probability of exceeding $\mathrm{R}$ in an uncorrelated set of samples, see Table 2a and 2b). We also tested the correlations between FM and OC inventory and other common mineralogical measurements, as well

as the relationship between OC inventory, weighted ${ }^{14} \mathrm{C}$ inventory, and clay content. We tested correlations between OC inventory and a suite of minerals present in the clay fraction of these soils (smectite, vermiculite, mica, kaolin, and total interlayer minerals). In the top m, we saw no other significant correlations with variables besides $\mathrm{Al}_{\mathrm{py}}$ and $\mathrm{Fe}_{\mathrm{py}}$ (Table 2a). Finally, we tested correlations on a horizon basis (A, AB, B) rather than a depth integrated basis (for example, $\mathrm{Al}_{\mathrm{py}}$ vs. $\mathrm{C}_{\text {tot }}$ within A horizon samples only). When grouped by horizon, a second pattern developed: in the AB horizon, correlations with $\mathrm{Al}_{\text {ox-py }}$ began to appear (representing noncrystallines such as allophane- and imogolitetype minerals), and in the $\mathrm{B}$ horizon, the correlation between $\mathrm{Al}_{\mathrm{ox}-\mathrm{py}}$ and the weighted soil FM was the most significant present (Table 2b).

\section{Discussion}

\section{A. Organo-metal chelates are important in top meter carbon storage}

Although $\mathrm{Al}_{\text {ox-py }}$ correlates very well with turnover time in other soils (especially Andisols; see [Basile et al., 2004; Torn et al., 1997]), in the Mollisols, Inceptisols, and Alfisols that occupy the Mattole terraces, this variable is not a good predictor of carbon 
storage in the top meter ( $\mathrm{R} \sim 0.7, \mathrm{p}>30 \%$, see Table $2 \mathrm{a})$. Instead, $\mathrm{S}_{\mathrm{py}}$ correlates very strongly with carbon storage in the top meter and in the A horizon (e.g. OC inventory vs. $\mathrm{Al}_{\mathrm{py}}$ has an $\mathrm{R}^{2}=0.999$ for A horizons). This suggests that at the Mattole site, noncrystalline minerals are not storing carbon effectively in the upper horizons, and/or that their concentration in the soils is too low to cause measurable influence in the upper meter of soil. Indeed, the concentration of $\mathrm{Al}_{\mathrm{ox}}$ in the Mattole soil is much lower than that at the Hawaii sites of Torn et al. (1997), less than 1\% at the highest concentration Mattole site compared to greater than $60 \%$ at some of the Hawaii Andisol sites. Within the Mattole terrace soils, the concentration of $\mathrm{Al}_{\mathrm{py}}$ and $\mathrm{Fe}_{\mathrm{py}}$ are two to four times higher than that of $\mathrm{Al}_{\text {ox-py }}$ and $\mathrm{Fe}_{\text {ox-py }}$ [Merritts et al., 1991].

We consider next the carbon storage potential of these soils by calculating how much carbon could be held if all of the available 'chelatable' $\mathrm{Al}$ and Fe (represented as $\mathrm{S}_{\mathrm{py}}$ ) were bound up in an organo-metal complex. This approach also gives us a sense of the importance of organo-metal chelation in carbon storage. We use the ratio of C to $\mathrm{S}_{\mathrm{py}}$ to understand how much of the soil carbon is bound in these complexes. To use this ratio, we need to make assumptions about the general charge state of soil organic matter (how many charges in each organic molecule are available for interaction with metals), and the actual structure of $\mathrm{Al}$ and $\mathrm{Fe}$ cations in the soils (e.g. as single cations like $\mathrm{Fe}^{3+}$, or polycations such as $\mathrm{Fe}(\mathrm{OH})_{2}{ }^{+}$).

Using approximations from Oades [Oades, 1989], each OC functional group can be thought of as having $\sim 6$ carbons associated with one negative charge. If every OC functional group was bound to a metal ion and all metal ions existed in the +1 charge state (as polycations) the molar $\mathrm{C} / \mathrm{S}_{\mathrm{py}}$ ratio would be 6 . This ratio gives a rough estimate 
of whether enough $\mathrm{Al}$ and Fe ions exist in the soil to be a significant influence on soil carbon storage mechanisms: a number much higher than 6 indicates that there is not enough $S_{\text {py }}$ to bind up much OC, while a number much lower than 6 indicates currently unused carbon storage potential.

We can raise or lower our estimate for this saturation value of $C / S_{p y}$ through a number of assumptions: some OC functional groups will not be sterically available to react with a metal ion (raising the $\mathrm{C} / \mathrm{S}_{\mathrm{py}}$ ratio); more than one functional group can interact with a metal ion (lowering the $\mathrm{C} / \mathrm{S}_{\mathrm{py}}$ ratio); and metal ions can exist as polycations (raising the $\mathrm{C} / \mathrm{S}_{\mathrm{py}}$ ratio) [Oades, 1989]. Bonding of all OC to $\mathrm{S}_{\mathrm{py}}$ seems to be indicated by $\mathrm{C} / \mathrm{S}_{\mathrm{py}}$ ratios between 2 and 10 [Oades, 1989]. $\mathrm{C} / \mathrm{S}_{\mathrm{py}}$ ratios at the Mattole chronosequence range from 30-50 in the surface of younger soils, to $S_{p y}$ values of 4-10 in the surface of intermediate and older soils and below about $40 \mathrm{~cm}$ for all soils (see Figure 3). This suggests that carbon storage in the surface of less developed soils is not dominated by chelation, but that in surface of more developed soils this mechanism is important, and below about $40 \mathrm{~cm}$, this control may be the single most significant parameter in the system.

\section{B. Significance of amorphous aluminum at depth: A shift in carbon storage mechanisms}

We move next from a meter-integrated approach to carbon storage to a perspective that considers storage by horizon. Although little carbon is stored within the Mattole terrace soils’ B horizons $\left(1.0 \pm 0.7 \mathrm{~g} / \mathrm{cm}^{2}\right.$ in B horizons vs. $4.1 \pm 1.9 \mathrm{~g} / \mathrm{cm}^{2}$ in the top meter), soil development and carbon storage are inextricably linked, and considering 
how carbon and minerals interact deeper in the soil and by horizon gives a mechanistic perspective on carbon storage processes.

From the $\mathrm{A}$ to the $\mathrm{AB}$ to the $\mathrm{B}$ horizon, the significance of the correlation between organic carbon storage variables and organo-metal chelates decreases and the significance of amorphous minerals, specifically those represented by $\mathrm{Al}_{\text {ox-py }}$, increases. In the B horizon, the only mineralogical variable correlated with carbon storage is the concentration of $\mathrm{Al}_{\text {ox-py }}$ (Table 2b). This shift from chelation-dominated storage to amorphous mineral-dominated storage is relevant because it is a component of the mechanism that creates Spodosols [Lundström et al., 2000].

In Spodosols, large quantities of low- and high-molecular weight organic acids chelate $\mathrm{Al}$ and $\mathrm{Fe}$ in the surface horizons, and the transport of these organo-metal chelates to deeper horizons creates a unique soil morphology, characterized by a white, primary mineral-rich E horizon overlying a dark, organic and sesquioxide-rich spodic horizon. Once chelates reach the $\mathrm{B}$ horizon, the organo-metal bond is broken, $\mathrm{Al}$ and $\mathrm{Fe}$ go on to form amorphous inorganics (like imogolite, allophane, and ferrihydrite), which create new surfaces (and a new mechanism) for organic carbon storage [Lundström et al., 2000; Skjemstad, 1992; Skjemstad et al., 1992].

Translocation of clays has masked the formation of a spodic horizon within the Mattole soils, but carbon storage appears to remain dominated by the process of formation, transport, and precipitation of organo-metal complexes. The presence of this mechanism outside of Spodosols and the correlation of this mechanism with slow carbon turnover times suggests that the formation and transport of organo-metal complexes may be a significant carbon storage mechanism in a broader range of soils than previously 
thought. Our radiocarbon results suggest that this process is active in other soil orders, and may dominate carbon storage in acid soils without a visible Spodic horizon. We suggest that instead of being controlled by the presence of a forest ecosystem, this process is fundamentally one of chemical weathering: soils must have experienced enough water flux to leach exchangeable Ca from the system, but not so much weathering as to convert all amorphous and metastable intermediates into crystalline minerals. On a global scale, this process is driven by high enough precipitation to support moist grasslands and forests.

This process is both climate and time dependent: young soils experiencing high rainfall may still have too much exchangeable $\mathrm{Ca}$ for this process to be active; on the other hand, old soils under moderate rainfall conditions may be dominated by a pozolization-like process. Carbon storage via $\mathrm{Al}^{3+}$ and $\mathrm{Fe}^{3+}$ chelation occurs once a system has experienced enough precipitation to cross a pedogenic threshhold [Chadwick and Chorover, 2001], flushing out $\mathrm{Ca}^{2+}$ ions and decreasing the soil $\mathrm{pH}$ to a point where Al-hydroxy complexes become soluble enough to engage in the process of organo-metal chelation and transport.

\section{Conclusions}

The vulnerability of the Earth's > 1500 Gt of soil OC [Amundson, 2001] to decomposition depends on the mechanisms controlling OC storage. Combining ${ }^{14} \mathrm{C}$ measurements with standard soil chemical extractions, we show that carbon storage and turnover in soils from our moist temperate grassland site are most closely related to proxies for the concentration of organo-metal complexes. Our conceptual model for the mechanism of carbon storage within this site is similar to the mechanism that creates soils 
within the Spodosol order: organic matter bonds with $\mathrm{Al}$ and Fe at the soil surface, organo-metal complexes illuviate and become insoluble at the $\mathrm{B}$ horizon, where $\mathrm{Al}$ and Fe are released to form amorphous minerals like allophane and ferrihydrite, creating new surfaces for carbon storage. Within the B horizon, the most significant mechanism of OC storage changes from organo-metal chelation to bonding between OC and amorphous minerals. The dominance of this Spodosol-like mechanism in carbon storage at the Mattole suite (containing Mollisols, Inceptisols, and an Alfisol) suggests that this process may be an important control on the rate of turnover of intermediate-timescale soil carbon in moist ecosystems, even when it is not reflected in obvious soil horizon patterns.

\section{Acknowledgements}

We thank Dave Hendricks for supplying mineralogical data. We thank Paula Zermeno, Brian Franz and other staff at the Center for Accelerator Mass Spectrometry at LLNL for assistance in target preparation, Sue Trumbore, Josh Schimel, Paula Reimer, and Bud Burke for thoughtful advice, and Andy Allen and Sarah Aciego for help digging soil pits. This work was performed in part under the auspices of the U.S. Department of Energy by University of California, Lawrence Livermore National Laboratory under Contract No. W-7405-Eng-48. CAM and OAC acknowledge funding from UCOP CLE, and CAM additionally acknowledges the support of the Anne Les AAUW Fellowship. 


\section{Figure Captions:}

Figure 1: Mattole terrace soil sampling site.

Figure 2a: Organic carbon inventory vs. terrace.

Figure 2b: Weighted FM inventory vs. terrace. Low numbers indicate less ${ }^{14} \mathrm{C}$ and more effective OC storage.

Figure 3: Moles of carbon per moles of $S_{p y}$, where $S_{p y}=\mathrm{Al}_{p y}+\mathrm{Fe}_{\mathrm{py}}$. 
Table 1: top meter inventories at Mattole terraces. Units are $\mathrm{g} / \mathrm{cm}^{2}$ except for $\mathrm{C} / \mathrm{N}$ and weighted FM, which are unitless.

\begin{tabular}{cccccccccccc} 
terrace & $\mathrm{OC}$ & $\mathrm{C} / \mathrm{N}$ & $\begin{array}{c}\text { weighted } \\
\text { inventory }\end{array}$ & $\mathrm{Fe}_{\mathrm{py}}$ & $\mathrm{Al}_{\mathrm{py}}$ & $\mathrm{Fe}_{\mathrm{d}}$ & $\mathrm{Fe}_{\text {ox-py }}$ & $\mathrm{Al}_{\text {ox-py }}$ & $\mathrm{Fe}_{\mathrm{d}-\mathrm{ox}}$ & clay \\
\hline $240 \mathrm{ka}$ & 4.61 & 11.89 & 0.838 & 0.454 & 0.609 & 1.779 & 0.138 & 0.074 & 1.188 & 27 \\
$124 \mathrm{a} \mathrm{ka}$ & 3.76 & 12.90 & 0.825 & 0.394 & 0.630 & 1.841 & 0.289 & 0.213 & 1.158 & 32.1 \\
$124 \mathrm{~b} \mathrm{ka}$ & 6.22 & 12.68 & 0.811 & 0.533 & 0.845 & 0.533 & 0.384 & 0.299 & 0.831 & 25.0 \\
$118 \mathrm{ka}$ & 6.47 & 12.26 & 0.814 & 0.489 & 0.823 & 0.489 & 0.391 & 0.288 & 0.805 & 22.5 \\
$40 \mathrm{ka}$ & 3.32 & 11.63 & 0.881 & 0.307 & 0.396 & 0.307 & 0.097 & 0.050 & 1.338 & 28.7 \\
$29 \mathrm{ka}$ & 3.22 & 10.97 & 0.938 & 0.231 & 0.221 & 0.231 & 0.230 & 0.010 & 0.360 & 8.7 \\
$3.9 \mathrm{ka}$ & 0.82 & 11.77 & 0.943 & 0.093 & 0.049 & 0.093 & 0.670 & 0.094 & 0.341 & 2.58
\end{tabular}


Table 2a: correlations between OC inventories, FM inventories, and mineralogical properties in the top meter of soils. ${ }^{* *}$ signifies $\mathrm{p}<0.005$; * means $\mathrm{p}<0.01$. Kaolin, smectite, vermiculite, mica, and total interlayer minerals were measured on the clay fraction only; all other properties were measured on the $<2 \mathrm{~mm}$ fraction.

\begin{tabular}{cccc}
\multicolumn{4}{c}{ top meter correlations } \\
OC vs. & $\mathrm{R}$ & $\begin{array}{c}\text { weighted } \mathrm{FM} \\
\text { inventory vs. }\end{array}$ & $\mathrm{R}$ \\
\hline $\mathrm{Fe}_{\mathrm{py}}$ & $0.953^{* *}$ & $\mathrm{Fe}_{\mathrm{py}}$ & $0.950^{* *}$ \\
$\mathrm{Al}_{\mathrm{py}}$ & $0.946^{* *}$ & $\mathrm{Al}_{\mathrm{py}}$ & $0.975^{* *}$ \\
$\mathrm{Fe}_{\mathrm{dcb}}$ & 0.236 & $\mathrm{Fe}_{\mathrm{dcb}}$ & 0.564 \\
$\mathrm{Fe}_{\mathrm{ox}-\mathrm{py}}$ & 0.299 & $\mathrm{Fe}_{\mathrm{ox}-\mathrm{py}}$ & 0.247 \\
$\mathrm{Al}_{\text {ox-py }}$ & 0.703 & $\mathrm{Al}_{\text {ox-py }}$ & 0.787 \\
$\mathrm{Fe}_{\mathrm{dcb}-\mathrm{ox}}$ & 0.354 & $\mathrm{Fe}_{\mathrm{dcb}-\mathrm{ox}}$ & 0.631 \\
clay & 0.597 & clay & 0.827 \\
kaolin & 0.116 & kaolin & 0.306 \\
smectite & 0.335 & smectite & 0.348 \\
vermiculite & 0.37 & vermiculite & 0.359 \\
mica & 0.08 & mica & 0.647 \\
total interlayer & 0.21 & total interlayer & 0.436
\end{tabular}


Table 2b: correlations between OC inventories, FM inventories, and mineralogical properties in the top meter of soils. ${ }^{* *}$ signifies $\mathrm{p}<0.005$; * means $\mathrm{p}<0.01$.

\begin{tabular}{cccc}
\multicolumn{4}{c}{ A horizon correlations } \\
OC vs. & $\mathrm{R}$ & $\begin{array}{c}\text { weighted FM } \\
\text { inventory vs. }\end{array}$ & $\mathrm{R}$ \\
$\mathrm{C} / \mathrm{N}$ & 0.174 & $\mathrm{C} / \mathrm{N}$ & 0.003 \\
${ }^{13} \mathrm{C}$ & 0.548 & ${ }^{13} \mathrm{C}$ & 0.814 \\
$\mathrm{FM}$ & 0.798 & $\mathrm{OC}$ & 0.798 \\
$\mathrm{Fe}_{\mathrm{py}}$ & 0.198 & $\mathrm{Fe}_{\mathrm{py}}$ & 0.091 \\
$\mathrm{Al}_{\text {py }}$ & $0.999^{* *}$ & $\mathrm{Al}_{\text {py }}$ & 0.808 \\
$\mathrm{Fe}_{\mathrm{DCB}}$ & $0.986^{* *}$ & $\mathrm{Fe}_{\mathrm{DCB}}$ & 0.872 \\
$\mathrm{Fe}_{\text {ox-py }}$ & 0.777 & $\mathrm{Fe}_{\text {ox-py }}$ & 0.764 \\
$\mathrm{Al}_{\text {ox-py }}$ & $0.945^{* *}$ & $\mathrm{Al}_{\text {ox-py }}$ & 0.780 \\
$\mathrm{Fe}_{\text {DCB-ox }}$ & $0.950^{* *}$ & $\mathrm{Fe}_{\mathrm{DCB}-\mathrm{ox}}$ & 0.822 \\
clay & $0.979 * *$ & clay & 0.831
\end{tabular}

AB horizon correlations

\begin{tabular}{|c|c|c|c|}
\hline OC vs. & $\mathrm{R}$ & $\begin{array}{l}\text { weighted FM } \\
\text { inventory vs. }\end{array}$ & $\mathrm{R}$ \\
\hline $\mathrm{C} / \mathrm{N}$ & 0.403 & $\mathrm{C} / \mathrm{N}$ & 0.532 \\
\hline${ }^{13} \mathrm{C}$ & 0.416 & ${ }^{13} \mathrm{C}$ & 0.750 \\
\hline $\mathrm{FM}$ & 0.649 & OC & 0.649 \\
\hline $\mathrm{Fe}_{\mathrm{py}}$ & $0.904 *$ & $\mathrm{Fe}_{\mathrm{py}}$ & 0.882 \\
\hline $\mathrm{Al}_{\mathrm{py}}$ & 0.837 & $\mathrm{Al}_{\mathrm{py}}$ & $0.942 * *$ \\
\hline $\mathrm{Fe}_{\mathrm{DCB}}$ & $0.903 *$ & $\mathrm{Fe}_{\mathrm{DCB}}$ & 0.836 \\
\hline $\mathrm{Fe}_{\text {ox-py }}$ & 0.439 & $\mathrm{Fe}_{\text {ox-py }}$ & 0.707 \\
\hline $\mathrm{Al}_{\text {ox-py }}$ & 0.758 & $\mathrm{Al}_{\text {ox-py }}$ & $0.955 * *$ \\
\hline $\mathrm{Fe}_{\text {DCB-ox }}$ & 0.829 & $\mathrm{Fe}_{\text {DCB-ox }}$ & 0.649 \\
\hline clay & 0.872 & clay & 0.830 \\
\hline \multicolumn{4}{|c|}{ B horizon correlations } \\
\hline OC vs. & $\mathrm{R}$ & FM vs. & $\mathrm{R}$ \\
\hline $\mathrm{C} / \mathrm{N}$ & 0.035 & $\mathrm{C} / \mathrm{N}$ & $0.905^{*}$ \\
\hline${ }^{13} \mathrm{C}$ & 0.227 & ${ }^{13} \mathrm{C}$ & 0.796 \\
\hline FM & 0.168 & OC & 0.168 \\
\hline $\mathrm{Fe}_{\mathrm{py}}$ & 0.779 & $\mathrm{Fe}_{\mathrm{py}}$ & 0.228 \\
\hline $\mathrm{Al}_{\mathrm{py}}$ & 0.294 & $\mathrm{Al}_{\mathrm{py}}$ & 0.808 \\
\hline $\mathrm{Fe}_{\mathrm{DCB}}$ & 0.319 & $\mathrm{Fe}_{\mathrm{DCB}}$ & 0.284 \\
\hline $\mathrm{Fe}_{\text {ox-py }}$ & 0.159 & $\mathrm{Fe}_{\text {ox-py }}$ & 0.009 \\
\hline $\mathrm{Al}_{\text {ox-py }}$ & 0.324 & $\mathrm{Al}_{\text {ox-py }}$ & $0.908 * *$ \\
\hline $\mathrm{Fe}_{\text {DCB-ox }}$ & 0.278 & $\mathrm{Fe}_{\text {DCB-ox }}$ & 0.398 \\
\hline clay & 0.276 & clay & 0.593 \\
\hline
\end{tabular}


Table 3: Radiocarbon, $\delta^{13} \mathrm{C}$, bulk density, and percent organic carbon data. Italics indicates missing data points; values are calculated via averaging horizons above and below. These soils contained no carbonates therefore no acidification step was used in measurement of organic carbon. Terrace MT-SP 4b is identified in other publications as terrace WP-R.

Terrace: MT-SP5 240 ka

$\begin{array}{ccccccccc}\text { sample } & \text { horizon } & \begin{array}{c}\text { horizon } \\ \text { bottom }\end{array} & \begin{array}{c}\text { bulk } \\ \text { rho }\end{array} & \mathbf{p H} & \mathbf{\% O C} & \boldsymbol{\delta}^{\mathbf{1 3}} \mathbf{C} & \Delta^{\mathbf{1 4}} \mathbf{C} & \mathbf{F M} \\ 0-15 & \text { A1 } & 15 & 1.10 & 5.31 & 6.868 & -26.4 & -56.7 & 0.9504 \\ 15-33 & \text { A2 } & 33 & 0.90 & 5.26 & 6.319 & -25.9 & -143.8 & 0.8622 \\ 33-63 & \text { AB1 } & 63 & 1.00 & 5.35 & 4.44 & -25.7 & -202 & 0.8034 \\ 63-90 & \text { AB2 } & 90 & 1.00 & 5.43 & 4.145 & -25.5 & -260.3 & 0.7446 \\ 90-128 & \text { Bw } & 128 & 1.40 & 5.57 & 2.377 & -25.4 & -429.2 & 0.5745 \\ 128-173 & \text { Bt } & 173 & 1.40 & 5.09 & 0.15 & -25.05 & -559 & 0.4437 \\ 173-200 & \text { Bg } & 200 & 1.60 & 5.33 & 0.149 & -24.7 & -688.9 & 0.3129 \\ 200-231 & \text { Bs1 } & 231 & 1.60 & 5.78 & 0.167 & -24.7 & -711.1 & 0.2907 \\ 231-246 & \text { Bs2 } & 246 & 1.50 & 5.62 & 0.02 & -24.45 & -657 & 0.3447 \\ 246-257 & \text { BCg } & 257 & 1.70 & 5.84 & 0.075 & -24.2 & -603.4 & 0.3987 \\ 257-282 & \text { BCg } & 282 & 1.70 & 6.20 & 0.073 & -24.8 & -674.6 & 0.3274\end{array}$

Terrace: WP-O 118 ka

\begin{tabular}{|c|c|c|c|c|c|c|c|c|}
\hline sample & horizon & $\begin{array}{l}\text { horizon } \\
\text { bottom }\end{array}$ & $\begin{array}{c}\text { bulk } \\
\text { rho }\end{array}$ & pH & $\% \mathrm{OC}$ & $\delta^{13} \mathrm{C}$ & $\Delta^{14} \mathbf{C}$ & FM \\
\hline $0-15$ & A1 & 15 & 1.1 & 4.84 & 6.833 & -25.9 & -121.3 & 0.885 \\
\hline $15-40$ & A2 & 40 & 1.2 & 5.05 & 6.622 & -25.6 & -170.9 & 0.8347 \\
\hline $40-80$ & A3 & 80 & 1.1 & 5.08 & 5.947 & -25.5 & -207.4 & 0.7979 \\
\hline 80-98 & AB1 & 98 & 1.1 & 5.19 & 3.736 & -25.2 & -301.5 & 0.703 \\
\hline $98-127$ & AB2 & 127 & 1.2 & 5.08 & 3.663 & -25.2 & -350.8 & 0.6533 \\
\hline $127-151$ & Bt1 & 151 & 1.4 & 5.47 & 0.577 & -23.6 & -483.2 & 0.5193 \\
\hline 151-195 & Bt2 & 195 & 1.4 & 5.55 & 0.182 & -23.4 & -488.1 & 0.5143 \\
\hline 195-250 & C & 250 & 1.5 & 5.35 & 0.111 & -23 & -509.1 & 0.493 \\
\hline
\end{tabular}

Terrace: MT-SP 4a 124 ka

$\begin{array}{ccccccccc}\text { sample } & \text { horizon } & \begin{array}{c}\text { horizon } \\ \text { bottom }\end{array} & \begin{array}{c}\text { bulk } \\ \text { rho }\end{array} & \begin{array}{c}\text { pH } \\ \text { \%OOC }\end{array} & \boldsymbol{\delta}^{\mathbf{1 3}} \mathbf{C} & \Delta^{\mathbf{1 4}} \mathbf{C} & \text { FM } \\ 0-19 & \text { A1 } & 19 & 0.90 & 4.82 & 7.07 & -25 & -62.8 & 0.9428 \\ 19-44 & \text { AB1 } & 44 & 1.00 & 5.12 & 5.51 & -24.8 & -185.8 & 0.8191 \\ 44-61 & \text { AB2 } & 61 & 0.90 & 5.26 & 4.72 & -25.2 & -213.8 & 0.7910 \\ 61-97 & \text { Bw1 } & 97 & 1.30 & 5.67 & 0.96 & -24.6 & -422.5 & 0.5810 \\ 97-132 & \text { Bw2 } & 132 & 1.30 & 5.17 & 0.4 & -24.3 & -447.6 & 0.5558 \\ 132-182 & \text { Bw3 } & 182 & 1.30 & 5.19 & 0.24 & -23.8 & -500.4 & 0.5027 \\ 182-270 & \text { BC1 } & 270 & 1.40 & 5.22 & 0.21 & -24.6 & -752.8 & 0.2487 \\ 270-320 & \text { BC2 } & 320 & 1.40 & - & 0.62 & -25.6 & -294.2 & 0.7101\end{array}$

Terrace: MT-SP 4b 124 ka

$\begin{array}{ccccccccc}\text { sample } & \text { horizon } & \begin{array}{c}\text { horizon } \\ \text { bottom }\end{array} & \begin{array}{c}\text { bulk } \\ \text { rho }\end{array} & \mathbf{p H} & \mathbf{0 O C} & \boldsymbol{\delta}^{\mathbf{1 3}} \mathbf{C} & \Delta^{\mathbf{1 4}} \mathbf{C} & \mathbf{F M} \\ 0-16 & \text { A1 } & 16 & 1.00 & 5.08 & 8.212 & -26.6 & -27.3 & 0.9787 \\ 16-49 & \text { A2 } & 49 & 1.00 & 5.11 & 6.292 & -25.8 & -182.6 & 0.8224 \\ 49-65 & \text { A3 } & 65 & 1.00 & 5.09 & 6.546 & -25.8 & -201.8 & 0.8031 \\ 65-108 & \text { AB } & 108 & 1.00 & 5.34 & 4.142 & -25.5 & -324.2 & 0.6799\end{array}$




$\begin{array}{lcccccccc}108-131 & \text { AB } & 131 & 1.10 & 5.36 & 2.681 & -25.1 & -418 & 0.5856 \\ 131-156 & \text { Bw1 } & 156 & 1.20 & 5.39 & 1.031 & -24.7 & -557.8 & 0.4449 \\ 156-183 & \text { Bw2 } & 183 & 1.10 & 5.46 & 0.821 & -24.95 & -641.4 & 0.36085 \\ 183-204 & \text { Bw3 } & 204 & 1.60 & 5.32 & 0.423 & -25.2 & -724.9 & 0.2768 \\ 204-241 & \text { BC1 } & 241 & 1.80 & 5.26 & 0.255 & -24.6 & -705.7 & 0.2962 \\ 241-256 & \text { BC2 } & 256 & 1.80 & 5.25 & 0.323 & -24 & -591.5 & 0.411\end{array}$

Terrace: MT-SP 240 ka

$\begin{array}{ccccccccc}\text { sample } & \text { horizon } & \begin{array}{c}\text { horizon } \\ \text { bottom }\end{array} & \begin{array}{c}\text { bulk } \\ \text { rho }\end{array} & \begin{array}{c}\text { pH } \\ \text { \%OC }\end{array} & \boldsymbol{\delta}^{\mathbf{1 3}} \mathbf{C} & \Delta^{\mathbf{1 4}} \mathbf{C} & \mathbf{F M} \\ 0-5 & \text { A } 1 & 5 & 1.00 & 4.79 & 5.69 & -27.6 & 75.3 & 1.0819 \\ 5-13 & \text { A2 } & 13 & 1.20 & 4.94 & 5.12 & -27.2 & 46.3 & 1.0526 \\ 13-30 & \text { A B1 } & 30 & 1.30 & 4.91 & 3.85 & -26.2 & -89.5 & 0.9160 \\ 30-43 & \text { A B2 } & 43 & 1.20 & 5.23 & 3.03 & -26.1 & -132 & 0.8733 \\ 43-53 & \text { A B3 } & 53 & 1.10 & 5.09 & 3.01 & -26 & -138.1 & 0.8672 \\ 53-74 & \text { Bw1 } & 74 & 1.30 & 5.29 & 1.84 & -26 & -291.3 & 0.7130 \\ 74-104 & \text { Bw2 } & 104 & 1.30 & 5.31 & 0.99 & -25.7 & -330.3 & 0.6737 \\ 104-147 & \text { B C1 } & 147 & 1.40 & 5.42 & 0.33 & -25.7 & -298.7 & 0.7056 \\ 147-173 & \text { Ccv } & 173 & 1.40 & 5.36 & 0.36 & -25.2 & -301.6 & 0.7027\end{array}$

Terrace: MT-SP 329 ka

$\begin{array}{ccccccccc}\text { sample } & \text { horizon } & \begin{array}{c}\text { horizon } \\ \text { bottom }\end{array} & \begin{array}{c}\text { bulk } \\ \text { rho }\end{array} & \begin{array}{c}\mathbf{p H} \\ \mathbf{0} \mathbf{0 O C}\end{array} & \boldsymbol{\delta}^{\mathbf{1 3}} \mathbf{C} & \Delta^{\mathbf{1 4}} \mathbf{C} & \mathbf{F M} \\ \text { 8-8 } & \text { A } & 8 & 1.10 & 5.42 & 4.69 & -28.3 & 115.6 & 1.122 \\ 23-38 & \text { A B1 } & 23 & 1.20 & 5.45 & 3.66 & -26.9 & -25 & 0.981 \\ 38-56 & \text { A B2 } & 38 & 1.30 & 5.67 & 3.05 & -26.6 & -58.6 & 0.947 \\ 56-74 & \text { A B3 } & 56 & 1.40 & 5.83 & 2.39 & -26 & -108.8 & 0.8966 \\ 74-94 & \text { Bw1 } & 74 & 1.40 & 5.92 & 2.20 & -26 & -131.5 & 0.8737 \\ 94-114 & \text { Bw2 } & 94 & 1.40 & 6.13 & 1.44 & -26 & -188.2 & 0.8168 \\ 114-135 & \text { Bw3 } & 114 & 1.40 & 5.92 & 1.80 & -26 & -229.7 & 0.7750 \\ & \text { Bw4 } & 135 & 1.40 & 5.72 & 2.53 & -26 & -277.7 & 0.7267\end{array}$

Terrace: MT-SP 8 3.9 ka

$\begin{array}{ccccccccc}\text { sample } & \text { horizon } & \begin{array}{c}\text { horizon } \\ \text { bottom }\end{array} & \begin{array}{c}\text { bulk } \\ \text { rho }\end{array} & \begin{array}{c}\text { pH } \\ \text { \%OOC }\end{array} & \boldsymbol{\delta}^{\mathbf{1 3}} \mathbf{C} & \Delta^{\mathbf{1 4}} \mathbf{C} & \mathbf{F M} \\ 0-22 & \text { A1 } & 22 & 1.40 & 6.69 & 1.211 & -27 & 21.1 & 1.027 \\ 22-48 & \text { A2 } & 48 & 1.40 & 7.20 & 0.332 & -27 & -298.6 & 0.706 \\ 48-65 & \text { A3 } & 65 & 1.40 & 7.40 & 0.289 & -25.8 & -169.5 & 0.836 \\ 65-80 & \text { A Bs } & 80 & 1.40 & 7.31 & 0.395 & -26 & -84.3 & 0.921 \\ 80-97 & \text { 2Bs1 } & 97 & 1.40 & 7.12 & 0.744 & -27.1 & -27.4 & 0.981 \\ 97-115 & \text { 2Bs2 } & 115 & 1.40 & 7.28 & 0.452 & -27 & -250.9 & 0.754 \\ 115-125 & \text { 2C } & 125 & 1.40 & 7.08 & 0.289 & -27.5 & -393.3 & 0.610\end{array}$


Alexiades, C.A., and M.L. Jackson, Quantitative clay mineralogical analysis of soils and sediments, Clays and Clay Minerals, 26, 35-68, 1966.

Amundson, R., The carbon budget in soils, Annual Review of Earth and Planetary Sciences, 29, 535-562, 2001.

Baldock, J.A., and J.O. Skjemstad, Role of the soil matrix and minerals in protecting natural organic materials against biological attack, Organic Geochemistry, 31 (78), 697-710, 2000.

Barnola, J.-M., D. Raynaud, C. Lorius, and N.I. Barkov, Historical $\mathrm{CO}_{2}$ record from the Vostok ice core, in Trends: A Compendium of Data on Global Change, Carbon Dioxide Information Analysis Center, Oak Ridge National Laboratory, Department of Energy, Oak Ridge, TN, 2003.

Basile, I., R. Amundson, W. Stone, C.A. Masiello, J.-Y. Bottero, F. Colin, F. Masin, D. Borschneck, and J.-D. Meunier, Mineralogical Control of Organic Carbon Dynamics in an Allophanic Soil (La Réunion), European Journal of Soil Science, in press, 2004.

Chadwick, O.A., and J. Chorover, The chemistry of pedogenic thresholds, Geoderma, 100 (3-4), 321-353, 2001.

Chadwick, O.A., L.A. Derry, P.M. Vitousek, B.J. Huebert, and L.O. Hedin, Changing sources of nutrients during four million years of ecosystem development, Nature, 397 (6719), 491-497, 1999.

Chadwick, O.A., E.F. Kelly, D.M. Merritts, and R.G. Amundson, Carbon Dioxide Consumption During Soil Development, Biogeochemistry, 24 (3), 115-127, 1994a.

Chadwick, O.A., C.G. Olson, D.M. Hendricks, E.F. Kelly, and R.F. Gavenda, Quantifying climatic effects on mineral weathering and neoformation in Hawaii., in 15th International Soil Science Conference, pp. 94-105, 1994b.

Chorover, J., M.K. Amistadi, and O.A. Chadwick, Surface charge evolution of soils during pedogenesis in Hawaii basalt, Geochimica Cosmochimica Acta, in press, 2004.

Guggenberger, G., and K. Kaiser, Dissolved organic matter in soil: challenging the paradigm of sorptive preservation, Geoderma, 113, 293-310, 2003.

Jackson, M.L., Free oxides, hydroxides, and amorphous aluminosilicates, in Methods of Soil Analysis, Part 1, Physical and Mineralogical Analysis, edited by C.A. Black, pp. 578-603, Agronomy No. 9, 1965.

Jackson, M.L., Soil Chemical Analysis: Advanced Course, published by the author, 1968.

Jackson, M.L., C.H. Lim, and L.W. Zelazny, Oxides, hydroxides, and aluminosilicates, in Methods of Soil Analysis, Part 1, Physical and Mineralogical Methods, edited by

A. Klute, pp. 101-150, Agronomy no. 9, 1986.

Jenny, H., Factors of soil formation: a system of quantitative pedology, $281 \mathrm{pp}$,, McGraw-Hill, New York, 1941.

Kaiser, K., and W. Zech, Defects in Estimation of Aluminum in Humus Complexes of Podzolic Soils By Pyrophosphate Extraction, Soil Science, 161 (7), 452-458, 1996. 
Kaiser, K., and W. Zech, Dissolved organic matter sorption by mineral constituents of subsoil clay fractions, Journal of Plant Nutrition and Soil Science-Zeitschrift Fur Pflanzenernahrung Und Bodenkunde, 163 (5), 531-535, 2000.

Lundström, U.S., N. van Breemen, D.C. Bain, P.A.W. van Hees, R. Giesler, J.P. Gustafsson, H. Ilvesniemi, E.M. Karltun, P.-A., M. Olsson, G. Riise, O.

Wahlberg, A. Bergelin, K. Bishop, R. Finlay, A.G. Jongmans, T. Magnusson, H. Mannerkoski, A. Nordgren, L. Nyberg, M. Starr, and L. Tau Strand, Advances in understanding the podzolization process resulting from a multidisciplinary study of three coniferous forest soils in the Nordic Countries, Geoderma, 94, 335-353, 2000.

Mayer, L., Relationships between mineral surfaces and organic carbon concentrations in soils and sediments, Chemical Geology, 114, 347-363, 1994.

Mayer, L., Extent of coverage of mineral surfaces by organic matter in marine sediments, Geochimica Cosmochimica Acta, 63 (2), 207-215, 1999.

Mayer, L., Organic matter-surface area relationships in acid soils, Soil Science Society of America Journal, 64, 250-258, 2001.

McKeague, J.A., J.E. Brydon, and N.M. Miles, Differentiation of forms of extractable iron and aluminum in soils, Soil Science Society of America Journal, 35, 33-38, 1971.

McKeague, J.A., and J.H. Day, Dithionite- and oxalate-extractable Fe and $\mathrm{Al}$ as aids in differentiating various classes of soils, Canadian Journal of Soil Science, 46, 1322, 1966.

Merritts, D.J., O.A. Chadwick, and D.M. Hendricks, Rates and Processes of Soil Evolution On Uplifted Marine Terraces, Northern California, Geoderma, 51 (1-4), 241-275, 1991.

Merritts, D.J., O.A. Chadwick, D.M. Hendricks, G.H. Brimhall, and C.J. Lewis, The Mass Balance of Soil Evolution On Late Quaternary Marine Terraces, Northern California, Geological Society of America Bulletin, 104 (11), 1456-1470, 1992.

Oades, J.M., An Introduction to Organic Matter in Mineral Soils, in Minerals in Soil Environments, edited by J.B. Dixon, and S.B. Weed, pp. 89-159, Soil Science Society of America, Madison, WI, 1989.

Percival, H.J., R.L. Parfitt, and N.A. Scott, Factors controlling soil carbon levels in New Zealand grasslands: Is clay content important?, Soil Science Society of America Journal, 64 (5), 1623-1630, 2000.

Powers, J.S., and W.H. Schlesinger, Relationships among soil carbon distributions and biophysical factors at nested spatial scales in rain forests of northeastern Costa Rica, Geoderma, 109, 165-190, 2002.

Ross, G.J., P.A. Schuppli, and C. Wang, Quantitative determination of vermiculite by a rubidium fixation method, Soil Science Society of America Journal, 53, 15881589, 1989.

Skjemstad, J.O., Genesis of Podzols on Coastal Dunes in Southern Queensland. III. The Role of Aluminum-Organic Complexes in Profile Development, Australian Journal of Soil Research, 30, 645-665, 1992.

Skjemstad, J.O., R.W. Fitzpatric, B.A. Zarcinas, and C.H. Thompson, Genesis of Podzols on Coastal Dunes in Southern Queensland. II. Geochemistry and Forms of 
Elements as Deduced from Various Soil Extraction Procedures, Australian Journal of Soil Research, 30, 615-644, 1992.

Stuiver, M., and H.A. Polach, Reporting of ${ }^{14} \mathrm{C}$ data, Radiocarbon, 19 (3), 355-363, 1977.

Stumm, W., Chemistry of the Solid-Water Interface, John Wiley and Sons, New York, 1992.

Torn, M.S., S.E. Trumbore, O.A. Chadwick, P.M. Vitousek, and D.M. Hendricks, Mineral control of soil organic carbon storage and turnover, Nature, 389 (6647), 170-173, 1997.

Trumbore, S.E., Potential responses of soil organic carbon to global environmental change, Proceedings of the National Academy of Sciences of the United States of America, 94 (16), 8284-8291, 1997.

Vitousek, P.M., O.A. Chadwick, T.E. Crews, J.H. Fownes, and D.M. Hendricks, Soil and ecosystem development across the Hawaiian Islands, GSA Today, 7, 1-8, 1997.

Vogel, J.S., D.E. Nelson, and J.R. Southon, ${ }^{14}$ C Background Levels in an Accelerator Mass Spectrometry System, Radiocarbon, 29 (3), 323-333, 1987. 


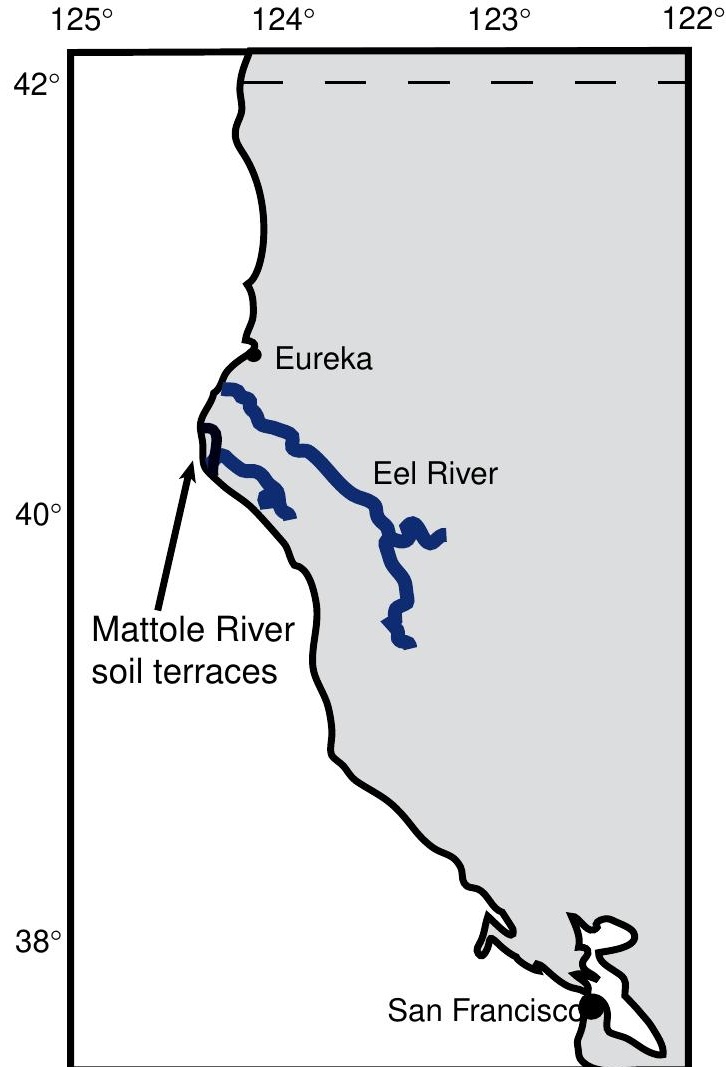


$1 \mathrm{~m}$ organic carbon inventory, $\mathrm{g} / \mathrm{cm}^{2} \quad$ Weighted fraction modern (FM)

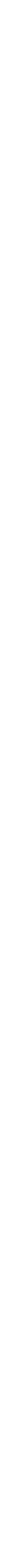


